\title{
Better Together: Connecting with Other Disciplines Builds Students' Own Skills and Professional Identity
}

\section{Dr. Donna C. Llewellyn, Boise State University}

Donna Crystal Llewellyn received her BA (major in Mathematics and minor in Economics) with High Honors from Swarthmore College in 1980. She went on to earn an MS in Operations Research from Stanford University in 1981 and a Ph.D. in Operations Research from Cornell University in 1984. After 30 years at Georgia Tech in a variety of roles, Donna became the Executive Director of the new Institute for STEM and Diversity Initiatives and Professor in the College of Innovation and Design at Boise State University in January 2015. Donna's current interests center around education issues in general, and in particular on increasing access and success of those traditionally under-represented and/or under-served in STEM higher education.

\section{Ms. Patricia Pyke, Boise State University}

Patricia Pyke is the Director of Research Development in the Division of Research and Economic Development at Boise State University.

\section{Dr. Sharon Paterson, Boise State University \\ Dr. R. Eric Landrum, Boise State University}

R. Eric Landrum is a professor of psychology at Boise State University, receiving his $\mathrm{PhD}$ in cognitive psychology from Southern Illinois University-Carbondale. His research interests center on the educational conditions that best facilitate student success as well as the use of SoTL strategies to advance the efforts of scientist-educators. He has over 300 professional presentations at conferences and published over 25 books/book chapters, and has published over 75 professional articles in scholarly, peer-reviewed journals. He has worked with over 300 undergraduate research assistants and taught over 13,000 students in 23 years at Boise State.

\section{Dr. Arthur Scarritt, Boise State University}

Arthur Scarritt is associate professor in the Department of Sociology at Boise State University. He is primarily interested in how different people reproduce and challenge the multiple forms of inequality within which they are immersed. His earlier work focused on indigenous populations in the Andes and he currently centers on students and higher education.

\section{Ms. Jocelyn B. S. Cullers, Boise State University}

Prof. Don L. Warner, Boise State University 


\section{Connecting with Other Disciplines Builds Students \\ Own Skills and Professional Identity}

\section{Background}

The Summer Research Community (SRC) at Boise State University brings STEM (science, technology, engineering, and mathematics) students together with faculty and other students from social sciences and humanities to form an interdisciplinary summer experience. The SRC was founded with impetus from a National Science Foundation grant to create efficiencies among NSF and other STEM education initiatives and to address critical junctures for undergraduate STEM students and faculty.

The SRC leadership team chose to focus on building community and facilitating growth in research skills and professional identity amongst participants in undergraduate research programs. Previous researchers have shown that engaging undergraduate students in research is associated with increases in retention. ${ }^{1,2,3}$ There is also evidence indicating that participation in research activities improves students' content knowledge of STEM disciplines and facilitates small-group learning, which effectively improves academic performance, attitudes toward the subject, and persistence. ${ }^{4,5}$ Further, well-implemented undergraduate research programs allow students to develop mentoring relationships with faculty members that have been linked to academic success. ${ }^{5}$ Participation in undergraduate research has also been linked to increases in graduate school attainment and in students' interest in science and engineering careers. ${ }^{1,6,7,8,9}$

In contrast to the above findings, there is little information on the relationship between participation in summer (or other semester-long) research experiences for undergraduates and growth in STEM-specific professional identity. Hunter et al. ${ }^{10}$ conducted a seminal study that focused on the development of professional identity, among other factors, experienced by rising seniors due to participation in a "Research Experience for Undergraduates" (REU) in a STEM field. In addition to the aforementioned benefits attributed to participation in undergraduate research, they found that students experienced shifts in attitudes toward "learning and working as a researcher," in that they reported that they assumed greater responsibility for their research, displayed increased independence and willingness to propose future experiments, and displayed increased acceptance of the realities of authentic research (e.g., frustrations, failures, etc.). Students demonstrated perceived inclusion in a broader STEM community, as demonstrated by gains in their confidence to contribute to science, acknowledging the significance of building a professional network with mentors and peers, and a "shift in their identity and sense of belonging." The authors contend that the participants' increase in identity as a scientist could be attributed to two key attributes. The first was related to an increased understanding and confidence in the nature of research. Specifically, participants critically evaluated their aptitude and intellectual wherewithal to conduct independent research. A second key factor was the consequence of attending or presenting at professional conferences, which provided a glimpse into their future careers as a STEM professional, and whether or not this was a desirable proposition. Thus, significant engagement in an undergraduate research experience, as afforded 
by summer research communities, provides opportunities for participants to translate their individualized experiences to an internalized identity as a STEM professional.

A second study focused on first- and second-year college students who participated in a 10 week residential REU program that took place in a chemistry department. ${ }^{11}$ The REU was found to promote growth in professional identity through the interactions with mentors and advisors, the responsibilities associated with conducting the research project, and the engagement in professional behaviors. The REU was found to increase the participants' self-reliance and selfconfidence, which are directly related to professional identity development. The students gained expert-level knowledge that they were eager to share with the greater community, which is indicative of changes in their perceptions of themselves as science professionals and internalization of identity. ${ }^{12}$ The participants believed they were part of the research community they were working within, which is arguably an indicator of membership of community and an expression of professional identity. The engagement in the REU was also found to impact the students on an emotional level, as the students shared feelings connected to their experience, which is notable given the coupling of emotions and professional competencies. ${ }^{13}$ It was postulated that the perceptions of high stakes by the students promoted a high level of cognitive and affective commitment to their experience, which was linked to the expectation of their performance and competency in the laboratory. Lastly, it was found that students transitioned from a performance goal orientation to more of a mastery approach towards problem solving through their involvement in the REU, which indicated that the students were self-identifying as science professionals.

Based on our analysis of the literature, we suggest that most research related to typical undergraduate research experiences are either discipline specific, or focus on select subdisciplines (i.e., only the physical sciences, or only the life sciences, etc.). Rarely is there collaboration between students and faculty conducting research in the humanities, engineering, mathematics, the sciences, and the social sciences. Although the financial and organizational benefits that arise from this type of collaboration are clear, the impact upon student development is unknown. It has been postulated that the most successful learning and research opportunities are the result of significant multidisciplinary integration. For example, the National Research Council in “A New Biology for the $21^{\text {st }}$ Century” stated that solving many of today's most critical problems will require the "integration into biology of physicists, chemists, computer scientists, engineers, and mathematicians." 14 Others have stated that in order for the United States to maintain our intellectual advantage, there must be a "convergence" of STEM disciplines to offer a "blueprint for innovation." 15 To prepare for this, students must become "well versed enough in varied disciplines and technologies to facilitate dialogue... and participate in integrated research."14 Potential employers also value interdisciplinary training. In a 2013 survey conducted for the Association of American Colleges and Universities, employers agree that "expecting students to develop the skills to conduct research collaboratively with their peers" will help prepare graduates for success in the workplace and these skills are "more important than their undergraduate major." ${ }^{16}$ Thus, exposing students to interdisciplinary research and collaboration early will help them prepare for future success as STEM 
professionals. As a result, we present our findings related to student growth as a result of participation in an interdisciplinary summer research community.

The opportunity to study the effects of research experiences in the context of interdisciplinarity arose in 2011 when our team decided to create efficiency among summer programs. That summer the university was hosting multiple NSF REU sites, several other NSF summer initiatives such as the Louis Stokes Alliance for Minority Participation (LSAMP) undergraduate research experience program, and research cohorts sponsored by agencies such as Department of Education (McNair Scholars) and National Institutes of Health. Participants included students from dozens of states and educational institutions, a few international students, and students from our home state and university. Most of these programs included an emphasis on underrepresented and first generation students. With a multiplicity of programs from various disciplines, the SRC leadership team recognized a unique opportunity to enrich students' summer experiences, without increasing the workload on each of the faculty mentors. We designed a summer program with two overarching goals: 1) Build interdisciplinary connections among students and programs, and 2) increase students' professional identity, knowledge, and skills related to research. As the program developed between 2011 and 2015, we fine-tuned the program and goals based on feedback, research, and evaluation.

\section{Structure}

Over the past six years, the 9-10 week Summer Research Community has brought together students across programs and included the following types of activities:

- Co-housing. Out-of-area students across REUs and other research programs were intermingled most years and lived together in student on-campus apartments.

- Orientation and training. One-time activities such as campus tours, city orientation, lab safety training, library methods, and research compliance introduction.

- Weekly research seminars. These were held at a regularly scheduled time such as Thursdays from 9:00-10:30 a.m. so that everyone could plan to fit them into their summer schedules. Seminars have included research ethics, research topics across STEM and non-STEM disciplines, collaboration, applying to graduate school, research-related careers, and much more.

- Networking events. Each summer included one or two major evening events at an off campus location such as a science center or museum, cultural center, or Shakespeare play. The program always involved the broader campus research community and included a buffet dinner, an intentional networking activity, and an educational activity/presentation.

- Social connection events. These usually included a kick-off picnic, rafting, attending events with high school scholars at campus programs, and other activities that arose spontaneously such as hiking or visiting a nature center.

- Presenting research. A strong emphasis on communicating about the students' research evolved and included several weekly seminars on communicating to various audiences, 
from children and the general public to peer researchers. A poster session began 2011 and developed into a full-fledged, two-day state-wide research conference in 2014.

\section{Formative Results - Qualitative Research}

In 2013, one of our researchers investigated interdisciplinarity and student success by studying how student interactions across disciplines during the summer REU groups in 2011 and 2012 impacted their acquisition of the resources they need to succeed. In general and within the context of higher education, these resources consist of human capital, social capital, and cultural capital, or, respectively: training, social connections, and the ability to function according to the standards set up in a specific social milieu. ${ }^{17}$

This study included 14 interviews of students who had participated in two NSF-supported REU programs (one in chemistry and one in mathematics) spanning two different summers. The interviews were done in 2013, so it was one to two years after the actual REU participation. This represents approximately half of the participants from those REUs and was split almost evenly between the two disciplines. The research instrument was developed after interviewing the professors in charge of the REUs and the student assistant heavily involved in administering summer non-lab times. As authoritative and "well informed" observers, these preparation interviews provided information about what REU students did outside of their labs, potential key issues students may have engaged each other with, and places for potential interaction.

There is an overriding tension in investigating the interdisciplinary creation of student resources for success between the preeminent importance of disciplinary resources and the great potential for innovation in the interdisciplinary arena. The highest potential lies in identifying interdisciplinary and disciplinary resources that complement each other, leading to an overall enhancement of student resources. The most salient example of this involved training students to explain their own work to people in other disciplines. This clearly enhanced the human and cultural capital of all people involved. The presenters in particular had great potential to learn more about their own work and discipline, and it provided them enhanced professionalization as they acquired greater skills to explain their work in meaningful ways to a broad audience. This importantly includes their primary audience of people within their own discipline, the kind of people who will eventually be accepting them into graduate school, hiring them, funding their grants and publications, and approving them for tenure and promotion.

Regarding the overall impact on student resources for success, the REU programs themselves generated some of the best kinds of social capital. While much of this came from withindisciplinary interactions, there is much to indicate that this bias resulted from the overall disciplinary focus of the REUs (and academia in general). The level of interdisciplinary-created social capital is directly and perhaps even proportionately related to the amount of interdisciplinary interactions during the REU. Importantly, this level was much lower than most students wanted. 
Student interdisciplinary acquisition of human capital was highly limited in the content of the other field. But students did acquire new appreciation of the other field (i.e., chemistry students appreciating mathematics, and vice versa), its methods, and its issues. Such appreciation was enhanced by the social capital of interdisciplinary camaraderie. The greatest use of interdisciplinarity, again, was by enhancing a student's own knowledge by speaking across disciplines. The REUs also laid considerable groundwork for potential future interdisciplinary activities, a highly valuable resource for pursing scientific innovations.

Cultural capital was interdisciplinarily enhanced, again, through the increased professionalization of improved presentations of self and research. Cross-disciplinary interactions with professors also enhanced the disciplinary demystifying of the student-professor relationship.

Other than these interactions with the faculty, the housing communities proved the preeminent means for interdisciplinary interactions to increase student resources. Living together enabled a high level of intimate interactions and easy friendships. Students worked together to find food and entertainment. Lasting memories emerged out of these experiences. There was also a sense of community that was gained through intensely challenging oneself and feeling liberated to use new forms of creative problem solving. Both the large social events and the conferences that bookended the REUs helped bring about potentials for the interdisciplinary creation of resources. But it was clear that these could only succeed to the extent that they were integrated into the daily living situations of the students.

The formal and informal cross-disciplinary interactions only amounted to about fifteen percent of students' time, either briefly in the residential communities or through intensive bursts during major events. Most of the cross-disciplinary interactions were informal. Only one research project was explicitly interdisciplinary and only involved two students. The remainder of the students did not formally work together. Given the intensity of the program, most student interaction in the dorms tended to be within disciplines. Residence life, though, made students highly aware of the rough similarity of experiences between disciplines. This created an informal camaraderie that inspired students to take greater interests in all of the work in the other discipline, as most readily through students going to all presentations at the conferences. The major events really evinced interdisciplinary interactions. These were mostly informal, enhancing social capital above all. The cross-disciplinary presentations of research were the only true format for cross-pollination, and these most immediately impacted students' knowledge about their own discipline; however, this opportunity also provided students with experience necessary for the highly burdensome background work necessary for interdisciplinary research.

The themes discovered in the qualitative study were used to expound on the goals, and then tailor activities to enhance the students' experiences and professional development opportunities. For example, the study showed that the ability to speak across disciplines was gained during the training sessions, which enabled students to present their findings to wider audiences and, therein, increase their overall embodied social capital as scientists. Therefore, the students were 
provided with more opportunities to present their research to a wide variety of audiences, from the Boys and Girls Club to professionals in their disciplines.

The expanded goal set became the following:

1) To foster connections and interdisciplinarity, the Summer Research Community will provide:

a) Opportunities for students to get to know students and faculty from other fields.

b) Opportunities for students to get to know students from other institutions.

c) Experiences where students feel they are part of a community of scholars.

d) Connections to other students and faculty that will continue after the summer.

e) Activities students consider enjoyable.

2) To foster knowledge and skills, the Summer Research Community will provide situations that enable students to:

a) Learn about research methods and topics applicable across many disciplines.

b) Gain increased knowledge or understanding of other fields besides their own.

c) Gain increased appreciation or interest in other fields besides their own.

d) Gain ability to explain their research to people outside their discipline.

e) Gain ability to explain their research to people within their discipline.

f) Identify as a researcher in their field or discipline.

\section{Quantitative Research and Results}

The researchers used the above goals to fine tune the SRC programming. To study if the programming changes were achieving these goals, the researchers then constructed a survey to be administered to the participating students at the end of the summer. The same survey has now been used for two years. It is being used as a tool of formative assessment to continue to improve the program, as well as to start to measure the impact of this kind of research community initiative.

The 12 evaluative questions that emerged from the qualitative research discussed above appear in Table 1. Additional questions about the value of different activities that occurred during the 10-week experience were also asked as part of the post-SRC survey.

After completing the 10-week SRC program, 40 survey responses (out of 103 participants; response rate $=38.8 \%$ ) were received in 2014, and 45 survey responses (out of 151 participants; response rate $=29.8 \%$ ) were received in 2015. For the distribution of participants by program in 2014 and 2015, see Table 3. 
Following the completion of the SRC program, participants were emailed and invited to complete an online evaluation administered via Qualtrics. Participants were asked to reply within three weeks of the invitation. Weekly reminders were sent to anyone who had not yet completed the survey at that time. After launching the survey, participants had unlimited time (within those three weeks) to complete the survey; their responses were recorded anonymously.

Independent-means $t$ tests were used to measure if there were significant changes in the scores reported from the 2014 SRC cohort to the 2015 SRC cohort. This data is summarized in Table 1 below. Two significant differences emerged. There was a significant difference between 2014 cohort scores $(M=4.60, S D=0.59)$ and 2015 cohort scores $(M=4.24, S D=0.71)$ on $1=$ strongly disagree to 5 = strongly agree answers to the item "I believe I can better explain my research to people in my own discipline,” $t(83)=2.49, p=.015$. There was also a significant difference between 2014 cohort scores $(M=78.70, S D=22.55)$ and 2015 cohort scores $(M=$ $68.26, S D=22.33$ ) on the $0-100$ level of agreement scale answers to the item "Because of the experiences this summer, I now feel like a researcher in my discipline,” $t(77)=2.06, p=.042$. If, however, a Bonferroni correction is applied due to multiple statistical tests being applied, the new significance level would be $.004(.05 / 12)$; thus, neither of the findings above would be considered statistically significant.

Since participants in the SRC come from a variety of backgrounds and programs, the researchers were interested in how those differences might impact these results. As mentioned earlier, the REUs have many opportunities built in that are aimed at similar goals of the SRC. Indeed, across the board, the students who were participants in formal REUs funded by NSF or NIH rated higher levels of agreement with all of the questions on the survey (see Table 2).

The participants were also asked to comment on one particular event in the SRC that they found most enjoyable and one which they found most valuable. Perhaps not surprising, the most enjoyable events across both summers were the organized social events; $25 \%$ of respondents indicated they enjoyed the plays at the Shakespeare Festival. The welcome picnic was mentioned by $14 \%$ of respondents, and the whitewater rafting trip was rated as highly enjoyable by $12 \%$. These questions included for an open-ended response field where the students could describe what led to their choice. The participants mentioned that while these were enjoyable in general, they also appreciated the networking aspects of all of the SRC events giving them the opportunity to meet the participants from the other programs in an informal setting. The following student comment is representative of the way students connected at a snack break before each of the weekly seminars.

"I think the period before the talks were the most enjoyable. I was able to meet with and talk with other researchers in my program as well as others I had just met."

The most valuable events were those around presenting their research to others - both learning how to create research posters and how to communicate their work to a general public, as well as the opportunities they were given to actually do each of these; $38 \%$ of survey respondents found 
the research poster instructional sessions to be the most useful; 27\% stated the research conference was particularly valuable. The main difference here between the NSF/NIH REU participants and the others was the value that the non NSF/NIH participants found in learning about the different perspectives from different fields and learning about ethics issues in research. Of the responders who mentioned these two categories of usefulness, non NSF/NIH participants accounted for $60 \%$ of the former and $75 \%$ of the latter. One explanation for this result is that this summer program gave students from humanities and arts an opportunity to learn about technical

Table 1

Evaluative Items, Response Scales, and Descriptive Statistics by Year

\begin{tabular}{|c|c|c|}
\hline & 2014 & 2015 \\
\hline Items & $M(S D)$ & $M(S D)$ \\
\hline 1. I got to know students from majors other than my own. & $4.00(0.88)$ & $3.76(1.05)$ \\
\hline $\begin{array}{l}\text { 2. I got to know faculty/staff from majors other than my } \\
\text { own. }\end{array}$ & $3.53(1.24)$ & $3.53(1.16)$ \\
\hline 3. I got to know students from other universities. & $3.83(1.13)$ & $3.91(1.08)$ \\
\hline $\begin{array}{l}\text { 4. I believe I have a better understanding of what } \\
\text { researchers in other fields do. }\end{array}$ & $4.23(0.77)$ & $4.18(0.83)$ \\
\hline $\begin{array}{l}\text { 5. I can now better appreciate the research in areas other } \\
\text { than my own. }\end{array}$ & $4.30(0.72)$ & $4.18(0.83)$ \\
\hline $\begin{array}{l}\text { 6. I believe I can better explain my research to people in } \\
\text { my own discipline. }\end{array}$ & $4.60(0.59)$ & $4.24(0.71)$ \\
\hline $\begin{array}{l}\text { 7. I believe I can better explain my research to people } \\
\text { outside of my own discipline. }\end{array}$ & $4.58(0.55)$ & $4.29(0.76)$ \\
\hline $\begin{array}{l}\text { 8. I learned about research methods and content areas } \\
\text { applicable to my major. }\end{array}$ & $4.35(1.03)$ & $3.89(1.15)$ \\
\hline $\begin{array}{l}\text { 9. I learned about research methods and content areas } \\
\text { applicable to majors other than my own. }\end{array}$ & $4.08(0.97)$ & $3.89(0.89)$ \\
\hline $\begin{array}{l}\text { 10. My connections to people I met will continue after } \\
\text { the summer. }\end{array}$ & $69.84(29.81)$ & $68.62(26.29)$ \\
\hline $\begin{array}{l}\text { 11. Because of the experiences this summer, I now feel } \\
\text { like I belong to a community of scholars. }\end{array}$ & $75.64(24.26)$ & 64.57 (26.19) \\
\hline $\begin{array}{l}\text { 12. Because of the experiences this summer, I now feel } \\
\text { like a researcher in my discipline. }\end{array}$ & $78.70(22.55)$ & $68.26(22.33)$ \\
\hline
\end{tabular}

Notes. Items 1-7 began with the stem "Because of my Summer Research Community experience..." and were answered on a scale of $1=$ strongly disagree to $5=$ strongly agree. Items 8-9 began with the stem "During my Summer Research Community experience..." and were answered on a scale of $1=$ strongly disagree to 5 = strongly agree. Items 10-12 were answered using a continuous scale from 0 to 100 indicating one's level of agreement with each statement. 
research in a very accessible way and in a forum with the very intent of interdisciplinarity. Moreover, ethics training is a requirement of NSF and NIH funded programs but is often omitted from informal undergraduate research programs, so including it in the SRC agenda helped to bring this important topic to all of the researchers.

As expected, there will be fluctuations in the evaluation of the SRC program from year to year. The benefit of the annual survey approach is that if there are dramatic fluctuations (either improvements or decrements), faculty and staff members will be aware of changes over time and may then probe further to investigate potential drivers in the changes in students' evaluative ratings. 


\section{Table 2}

Evaluative Items, Response Scales, and Descriptive Statistics by Year (by type of program) - Note that the "N's" are the number of students who self-reported being in that type of program. However, $N$ 's might be less for some of the questions due to participants not answering all of the posed questions.

\begin{tabular}{|c|c|c|c|c|c|c|c|c|}
\hline \multirow[b]{3}{*}{ Evaluative Item } & \multicolumn{8}{|c|}{2014 by Program Support } \\
\hline & \multicolumn{2}{|c|}{$\begin{array}{l}\text { NSF or NIH } \\
\text { REU } \\
\text { N }=20\end{array}$} & \multicolumn{2}{|c|}{$\begin{array}{l}\text { Other Program } \\
\qquad \mathbf{N}=17\end{array}$} & \multicolumn{2}{|c|}{$\begin{array}{l}\text { BOTH NSF/NIH REU } \\
\text { and Other Program } \\
\qquad \mathrm{N}=2\end{array}$} & \multicolumn{2}{|c|}{$\begin{array}{l}\text { Not reported } \\
\qquad \mathbf{N}=\mathbf{1}\end{array}$} \\
\hline & Mean & $\begin{array}{l}\text { Std. } \\
\text { dev. }\end{array}$ & Mean & $\begin{array}{l}\text { Std. } \\
\text { dev. }\end{array}$ & Mean & Std. dev. & Mean & Std. dev. \\
\hline $\begin{array}{l}\text { I got to know students from majors } \\
\text { other than my own. }\end{array}$ & 4.00 & 0.92 & 3.94 & 0.90 & 4.50 & 0.71 & 4.00 & $\begin{array}{l}\mathrm{n} / \mathrm{a} \text { - one } \\
\text { respondent }\end{array}$ \\
\hline $\begin{array}{l}\text { I got to know faculty/staff members } \\
\text { from majors other than my own. }\end{array}$ & 3.75 & 1.12 & 3.35 & 1.41 & 2.50 & 0.71 & 4.00 & $\begin{array}{l}\mathrm{n} / \mathrm{a} \text { - one } \\
\text { respondent }\end{array}$ \\
\hline $\begin{array}{l}\text { I got to know students from other } \\
\text { universities. }\end{array}$ & 4.35 & 0.81 & 3.29 & 1.21 & 3.00 & 1.41 & 4.00 & $\begin{array}{l}\mathrm{n} / \mathrm{a} \text { - one } \\
\text { respondent }\end{array}$ \\
\hline $\begin{array}{l}\text { I believe I have a better } \\
\text { understanding of what researchers in } \\
\text { other fields do. }\end{array}$ & 4.35 & 0.81 & 4.12 & 0.70 & 4.50 & 0.71 & 3.00 & $\begin{array}{l}\mathrm{n} / \mathrm{a} \text { - one } \\
\text { respondent }\end{array}$ \\
\hline $\begin{array}{l}\text { I can now better appreciate the } \\
\text { research in areas other than my own. }\end{array}$ & 4.45 & 0.60 & 4.18 & 0.81 & 4.50 & 0.71 & 3.00 & $\begin{array}{l}\mathrm{n} / \mathrm{a} \text { - one } \\
\text { respondent }\end{array}$ \\
\hline $\begin{array}{l}\text { I believe I can better explain my } \\
\text { research to people in my own } \\
\text { discipline. }\end{array}$ & 4.80 & 0.41 & 4.47 & 0.62 & 4.50 & 0.71 & 3.00 & $\begin{array}{l}\mathrm{n} / \mathrm{a} \text { - one } \\
\text { respondent }\end{array}$ \\
\hline $\begin{array}{l}\text { I believe I can better explain my } \\
\text { research to people outside of my own } \\
\text { discipline. }\end{array}$ & 4.65 & 0.49 & 4.59 & 0.51 & 4.50 & 0.71 & 3.00 & $\begin{array}{l}\mathrm{n} / \mathrm{a} \text { - one } \\
\text { respondent }\end{array}$ \\
\hline
\end{tabular}




\begin{tabular}{|c|c|c|c|c|c|c|c|c|}
\hline $\begin{array}{l}\text { I learned about research methods and } \\
\text { content areas applicable to my major. }\end{array}$ & 4.70 & 0.47 & 4.12 & 1.17 & 4.50 & 0.71 & 1.00 & $\begin{array}{l}\mathrm{n} / \mathrm{a} \text { - one } \\
\text { respondent }\end{array}$ \\
\hline $\begin{array}{l}\text { I learned about research methods and } \\
\text { content areas applicable to majors } \\
\text { other than my own. }\end{array}$ & 4.15 & 0.88 & 3.88 & 1.11 & 4.50 & 0.71 & 5.00 & $\begin{array}{l}\mathrm{n} / \mathrm{a} \text { - one } \\
\text { respondent }\end{array}$ \\
\hline $\begin{array}{l}\text { My connections to people I met will } \\
\text { continue after the summer. }\end{array}$ & 79.56 & 19.52 & 62.75 & 34.65 & 74.00 & 9.90 & 0.00 & $\begin{array}{l}\mathrm{n} / \mathrm{a} \text { - one } \\
\text { respondent }\end{array}$ \\
\hline $\begin{array}{l}\text { Because of the experiences this } \\
\text { summer, I now feel like I belong to a } \\
\text { community of scholars. }\end{array}$ & 81.16 & 19.11 & 78.14 & 19.65 & 43.50 & 23.33 & 0.00 & $\begin{array}{l}\mathrm{n} / \mathrm{a} \text { - one } \\
\text { respondent }\end{array}$ \\
\hline $\begin{array}{l}\text { Because of the experiences this } \\
\text { summer, I now feel like a researcher } \\
\text { in my discipline. }\end{array}$ & 83.79 & 17.59 & 81.33 & 17.12 & 50.00 & 14.14 & 0.00 & $\begin{array}{l}\mathrm{n} / \mathrm{a} \text { - one } \\
\text { respondent }\end{array}$ \\
\hline
\end{tabular}

\begin{tabular}{|c|c|c|c|c|c|c|c|c|}
\hline \multirow[b]{3}{*}{ Evaluative Item } & \multicolumn{8}{|c|}{2015 by Program Support } \\
\hline & \multicolumn{2}{|c|}{$\begin{array}{l}\text { NSF or NIH REU } \\
\qquad \begin{array}{l}\text { N }=24\end{array}\end{array}$} & \multicolumn{2}{|c|}{$\begin{array}{l}\text { Other Program } \\
\qquad \mathbf{N}=\mathbf{1 8}\end{array}$} & \multicolumn{2}{|c|}{$\begin{array}{c}\text { BOTH NSF/NIH REU } \\
\text { and Other Program } \\
\text { N }=2\end{array}$} & \multicolumn{2}{|c|}{$\begin{array}{l}\text { Not reported } \\
\qquad \mathbf{N}=1\end{array}$} \\
\hline & Mean & Std. dev. & Mean & $\begin{array}{l}\text { Std. } \\
\text { dev. }\end{array}$ & Mean & Std. dev. & Mean & Std. dev. \\
\hline $\begin{array}{l}\text { I got to know students from majors } \\
\text { other than my own. }\end{array}$ & 3.96 & 0.81 & 3.67 & 1.24 & 3.00 & 1.41 & 2.00 & $\begin{array}{l}\mathrm{n} / \mathrm{a}-\text { one } \\
\text { respondent }\end{array}$ \\
\hline $\begin{array}{l}\text { I got to know faculty/staff members } \\
\text { from majors other than my own. }\end{array}$ & 3.71 & 1.20 & 3.44 & 1.10 & 3.00 & 1.41 & 2.00 & $\begin{array}{l}\mathrm{n} / \mathrm{a} \text { - one } \\
\text { respondent }\end{array}$ \\
\hline $\begin{array}{l}\text { I got to know students from other } \\
\text { universities. }\end{array}$ & 4.33 & 0.64 & 3.39 & 1.29 & 4.50 & 0.71 & 2.00 & $\begin{array}{l}\mathrm{n} / \mathrm{a} \text { - one } \\
\text { respondent }\end{array}$ \\
\hline
\end{tabular}




\begin{tabular}{|c|c|c|c|c|c|c|c|c|}
\hline $\begin{array}{l}\text { I believe I have a better } \\
\text { understanding of what researchers in } \\
\text { other fields do. }\end{array}$ & 4.46 & 0.59 & 3.94 & 0.94 & 4.00 & 0.00 & 2.00 & $\begin{array}{l}\text { n/a - one } \\
\text { respondent }\end{array}$ \\
\hline $\begin{array}{l}\text { I can now better appreciate the } \\
\text { research in areas other than my own. }\end{array}$ & 4.33 & 0.70 & 4.11 & 0.90 & 4.00 & 0.00 & 2.00 & $\begin{array}{l}\mathrm{n} / \mathrm{a} \text { - one } \\
\text { respondent }\end{array}$ \\
\hline $\begin{array}{l}\text { I believe I can better explain my } \\
\text { research to people in my own } \\
\text { discipline. }\end{array}$ & 4.25 & 0.68 & 4.39 & 0.61 & 4.00 & 0.00 & 2.00 & $\begin{array}{l}\mathrm{n} / \mathrm{a} \text { - one } \\
\text { respondent }\end{array}$ \\
\hline $\begin{array}{l}\text { I believe I can better explain my } \\
\text { research to people outside of my own } \\
\text { discipline. }\end{array}$ & 4.25 & 0.79 & 4.50 & 0.51 & 4.00 & 0.00 & 2.00 & $\begin{array}{l}\mathrm{n} / \mathrm{a} \text { - one } \\
\text { respondent }\end{array}$ \\
\hline $\begin{array}{l}\text { I learned about research methods and } \\
\text { content areas applicable to my major. }\end{array}$ & 3.96 & 1.12 & 3.94 & 1.11 & 4.00 & 0.00 & 1.00 & $\begin{array}{l}\mathrm{n} / \mathrm{a} \text { - one } \\
\text { respondent }\end{array}$ \\
\hline $\begin{array}{l}\text { I learned about research methods and } \\
\text { content areas applicable to majors } \\
\text { other than my own. }\end{array}$ & 4.00 & 0.83 & 3.83 & 0.99 & 3.50 & 0.71 & 3.00 & $\begin{array}{l}\mathrm{n} / \mathrm{a} \text { - one } \\
\text { respondent }\end{array}$ \\
\hline $\begin{array}{l}\text { My connections to people I met will } \\
\text { continue after the summer. }\end{array}$ & 69.04 & 27.10 & 69.56 & 25.30 & 79.50 & 3.54 & 20.00 & $\begin{array}{l}\mathrm{n} / \mathrm{a} \text { - one } \\
\text { respondent }\end{array}$ \\
\hline $\begin{array}{l}\text { Because of the experiences this } \\
\text { summer, I now feel like I belong to a } \\
\text { community of scholars. }\end{array}$ & 58.78 & 24.76 & 78.50 & 21.47 & 46.00 & 19.80 & 12.00 & $\begin{array}{l}\mathrm{n} / \mathrm{a} \text { - one } \\
\text { respondent }\end{array}$ \\
\hline $\begin{array}{l}\text { Because of the experiences this } \\
\text { summer, I now feel like a researcher } \\
\text { in my discipline. }\end{array}$ & 66.48 & 20.60 & 76.50 & 17.90 & 54.50 & 27.58 & 5.00 & $\begin{array}{l}\mathrm{n} / \mathrm{a} \text { - one } \\
\text { respondent }\end{array}$ \\
\hline
\end{tabular}


Table 3

Composition of Summer Research Community Participants by Year

\begin{tabular}{lcc}
\cline { 2 - 3 } \multicolumn{1}{c}{ Program } & \multicolumn{2}{c}{ Year } \\
\hline NSF Mathematics REU & 2014 & 2015 \\
NSF Materials Science REU & 4 & 5 \\
NSF Materials Science RET & 6 & 7 \\
NSF Raptor Research REU & & 4 \\
NSF Software Security REU & 5 & 2 \\
NIH Idaho INBRE & & 1 \\
NSF Idaho EPSCoR/MURI & 7 & 8 \\
NSF LSAMP & 5 & 1 \\
Student Research Initiative & 2 & 3 \\
NSF STEP & 5 & 5 \\
McNair Scholars & 3 & 1 \\
IDoTeach/Noyce Scholars & 2 & 5 \\
ACS Project SEED & 1 & 3 \\
Other & 2 & 3 \\
\hline
\end{tabular}

Note. Within a year, participants could identify more than one program. 


\section{Limitations}

As this study focused on student perceptions of professional identity, interdisciplinary connections, and skill development, all the data collected was from the students' perspectives, via intensive interviews or post-program surveys. An extension of this study this coming summer will be to design a survey or interview protocol to collect faculty perceptions of student gains related to the goals and compare the results with the students' self-reported data. Anecdotally, faculty and staff involved in the summer programs have observed that many SRC students who present at the statewide summer research conference demonstrate presentation skills that set them apart from presenters who were not part of the SRC, with its rigorous focus on science communication at all levels. (The SRC students are a subset of the presenters at the summer state-wide conference.) Faculty mentors could also evaluate students' gains longer term. We have indicators that this would be a fruitful study of student development because there are groups of faculty and students who have continued to stay in touch with each other and present at conferences as follow-on to their summer research.

\section{Discussion and Conclusion}

The introduction of this paper discussed the need for future STEM professionals to participate in interdisciplinary communities. This is often discussed in terms of the need for future STEM researchers to understand other disciplines and to be able to communicate their results to the public. Drawing on results of this study, we conclude that an interdisciplinary summer research community provides a genuine environment where students in a variety of different fields gain exposure to and interact with people from myriad disciplines. Personal gains from these experiences will benefit students whether they go on to graduate school or enter the workforce. Although it is a goal of our and many student research programs to guide students toward graduate school, national data shows that most students who earn undergraduate degrees will enter the non-academic workforce upon graduation. "Professional skills for the engineering workplace include teamwork, communication, coordination, data analysis and problem solving," according to a literature review by Villachica et al. ${ }^{18}$ Indeed, these skills are similar to professional skills desired by employers in all fields, not just the STEM disciplines. ${ }^{19}$ There are many reports that indicate that research experiences promote the development of problem solving, analysis, and critical thinking skills for students in all fields of study. However, we also know that most college graduates will engage in some kind of knowledge work, and knowledge work is interdisciplinary by nature. Therefore, by design, the SRC seeks to foster these connections and to support the personal development of teamwork and communication skills that are so valuable in today's academic and non-academic workplaces.

\section{Acknowledgements}

This study is based upon work supported by the National Science Foundation under an Innovation Though Institutional Integration grant (NSF \# 0963659, Martin Schimpf, PI). Any opinions, findings, and conclusions or recommendations expressed in this paper are those of the 
authors and do not necessary reflect the views of the National Science Foundation. We also gratefully acknowledge the students who participated in the Summer Research Community, and the faculty and staff from the following projects at Boise State University who organized the Summer Research Community: NSF REU Program in Mathematics (NSF\#1062857 \& \#1359425, PI Liljana Babinkostova), NSF REU in Chemistry (NSF\#1005159, PI Don Warner), NSF REU in Materials for Energy and Sustainability (NSF\#1359344, PI Rick Ubic), NSF REU in Raptor Research (NSF\#1263167, PI Jim Belthoff), NSF REU for Software Security (NSF\#1461133, PI Dianxiang Yu), NIH Idaho INBRE (NIH\#P20GM103408, PI Carolyn HovdeBohach), NSF Idaho EPSCoR (NSF\#1301792, PI Shawn Benner), NSF LSAMP (NSF\#0901996, PI Martin Schimpf and NSF\#1410465, PI Sharon McGuire), NSF Noyce Program (NSF\#1240011, PI Louis Nadelson), Department of Education McNair Scholars (\#P217A120308, PI Greg Martinez), NSF STEP Program (NSF\#0856815, PI Janet Callahan), American Chemical Society Project SEED, and many other people and programs.

\section{References}

1. Lopatto, D. (2007). Undergraduate research experiences support science career decisions and active learning. CBE - Life Sciences Education, 6, 297.

2. Russell, S. H. "Evaluation of NSF support for undergraduate research opportunities: Synthesis Report." SRI International, 2006. http://csted.sri.com/content/evaluation-nsf-support-undergraduate-research-opportunitiesuro-synthesis-report; (accessed April, 2016).

3. Seevers, M., Knowlton, W., Pyke, P., Schrader, C., \& Gardner, J. (2006). Improving Engineering Undergraduate Retention via Research and Internships. Proceedings of the 2006 American Society for Engineering Education Annual Conference and Exposition. 11.734.1 - 11.734.10

4. Nadelson, L. S., Walter, L. \& Waterman, J. (2010). Undergraduate research experiences at different level of inquiry. Journal of STEM Education, 11(1\&2), 27- 44.

5. Springer, L.; Stanne, M. E.; Donovan, S. S. (1999). Effects of small-group learning on undergraduates in STEM: A meta-analysis. Review of Educational Research 19, 21.

6. Russell, S. H. "Evaluation of NSF support for undergraduate research opportunities: Synthesis Report." SRI International, 2006. http://csted.sri.com/content/evaluation-nsf-support-undergraduate-research-opportunitiesuro-synthesis-report; (accessed April, 2016).

7. Kardash, C. M. (2000). Evaluation of an undergraduate research experience. Journal of Educational Psychology, 92, 191. 
8. Seymour, E.; Hunter, A. B.; Laursen, S. L.; DeAntoni, T. (2004). Establishing the benefits of research experiences for undergraduates in the sciences: First findings from a three-year study. Science Education, 88, 493-534.

9. Zydney, A.; Bennett, J.; Shahid, A.; Bauer, K. (2002). Impact of Undergraduate Research Experience in Engineering. Journal of Engineering Education, 91, 151.

10. Hunter, A. B., Laursen, S.L. \& Seymour, E. (2007). Becoming a scientist: The role of undergraduate research in students' cognitive, personal, and professional development. Science Education, 91, 36-74.

11. Nadelson, L, Warner, D., Brown, E. (2015). Life’s Lessons in the Lab: A Summer of Learning from Undergraduate Research Experiences. Journal of STEM Education, 16, 5-12.

12. Baxter Magolda, M. B. (2002). Helping students make their way to adulthood: Good company for the journey. Around Campus, Jan - Feb 2002, 2-9.

13. Epstein, R. M., \& Hundert, E. M. (2002). Defining and assessing professional competence. Journal of the American Medical Association, 287, 226-35.

14. National Research Council; A New Biology for the 21st Century: Ensuring the United States Leads the Coming Biology Revolution; National Academies Press: Washington, DC; 2009. http://www.nap.edu/catalog.php?record_id=12764; (accessed January, 2016).

15. Massachusetts Institute of Technology; The Third Revolution: The Convergence of the Life Sciences, Physical Sciences, and Engineering.

http://dc.mit.edu/sites/dc.mit.edu/files/MIT\%20White\%20Paper\%20on\%20Convergence.pdf (accessed January 2016)

16. Hart Research Associates (2013) "It Takes More than a Major: Employer Priorities for College Learning and Student Success", Liberal Education, 99 (2). https://www.aacu.org/publications-research/periodicals/it-takesmore-major-employer-priorities-college-learning-and (accessed April, 2016).

17. Bourdieu, P. (1986). The forms of capital. In J. Richardson (Ed.) Handbook of Theory and Research for the Sociology of Education (New York, Greenwood), 241-258.

18. Villachica, S., Marker, A., Plumlee, D., Chegash, A. (2014). What's happening to Our “Freshout” Engineers?” Presentation at the Performance Improvement Conference, International Society for Performance Improvement, April 17, 2014.

19. Gardner, P., Kaylor, D., Mason S., Van Dyke, J., Zhu, P., \& Landrum, E. (2012). Collegiate Workforce Readiness Study. 